\title{
Environmental Factors Affecting Pseudothecial Development and Ascospore Production of Mycosphaerella citri, the Cause of Citrus Greasy Spot
}

\author{
S. N. Mondal and L. W. Timmer
}

University of Florida, Citrus Research and Education Center, 700 Experiment Station Road, Lake Alfred 33850.

Accepted for publication 16 July 2002.

\section{ABSTRACT}

Mondal, S. N., and Timmer, L. W. 2002. Environmental factors affecting pseudothecial development and ascospore production of Mycosphaerella citri, the cause of citrus greasy spot. Phytopathology 92:1267-1275.

Mycosphaerella citri, the cause of citrus greasy spot, produces pseudothecia and ascospores in decomposing leaf litter on the grove floor. In laboratory studies, the effect of wetting and drying and temperature on the formation, maturation, and production of pseudothecia and ascospores was evaluated on mature, detached grapefruit leaves. Production of pseudothecia was most rapid when leaves were soaked five times per week for $2 \mathrm{~h}$ per day, but pseudothecial density and total ascospore production were greatest when leaves were soaked three times per week for $2 \mathrm{~h}$ per day. In duration of wetting studies, $3 \mathrm{~h}$ per day, 3 days per week brought about the most rapid production, but 10 to $30 \mathrm{~min}$ per day resulted in production of the most pseudothecia and ascospores. Pseudo- thecia and ascospore production were greatest at $28^{\circ} \mathrm{C}$ and declined rapidly at lower and higher temperatures. Maturation of pseudothecia was slow at 20 and $24^{\circ} \mathrm{C}$, but production was high at $24^{\circ} \mathrm{C}$; at $32^{\circ} \mathrm{C}$, pseudothecia matured rapidly, but degenerated quickly. No mature pseudothecia were produced on leaves maintained continuously under wet conditions. In field studies, leaves were placed on the grove floor monthly from April 2000 to September 2001. Pseudothecia production was rapid during the summer rainy season from June to September. Pseudothecia produced on leaves placed in the grove from October to May developed and matured more slowly but were produced in much larger numbers than in summer. The number of days to first pseudothecial initials, 50\% maturation, first discharge of ascospores, leaf decomposition, as well as pseudothecial density and incidence, were negatively related to average temperature. Total ascospore production was unrelated to temperature.
Greasy spot, caused by Mycosphaerella citri, produces lesions on mature leaves of most citrus species resulting in premature defoliation of trees $(15,25,26)$. Excessive leaf loss can reduce yields up to $50 \%$ on susceptible species such as grapefruit (26). M. citri also produces greasy spot rind blotch on fruit, which reduces the acceptability of fruit for the fresh market. Greasy spot is a serious problem in the entire Caribbean Basin including Florida, the Caribbean islands, eastern Mexico, and Central America (4,15). Greasy spot-like diseases occur in Argentina, Australia, Japan, and other humid citrus areas (15).

In a series of studies in the 1970s, Whiteside $(20,21,24,25)$ elucidated the cause of greasy spot and described the basic biology of $M$. citri. Pseudothecia and ascospores are produced in decomposing leaf litter on the grove floor in late spring and early summer. Ascospores are airborne and are deposited on the leaf surface where they germinate and the fungus grows epiphytically for several weeks before penetrating the leaf. Conidia of the anamorph, Stenella citri-grisea (F. E. Fisher), are produced in small numbers on the epiphytic hyphae, but are not thought to play a major role in the epidemiology of the disease $(15,20)$. All infections occur through stomata, which are located primarily on the abaxial surface of citrus leaves. $M$. citri grows slowly in mesophyll and symptoms may not develop for 3 to 4 months after infection, depending on the susceptibility of the citrus species. In Florida, leaves of the spring growth are infected during the summer but do not show symptoms until November to December. Greasy spot-induced defoliation occurs in late winter and early

Corresponding author: S. N. Mondal; E-mail address; smondal@lal.ufl.edu

Publication no. P-2002-0925-01R

(c) 2002 The American Phytopathological Society spring. Formerly, peak ascospore release occurred in early June when the summer rains begin (14,20). In more recent years, peak ascospore release has occurred earlier, in March to May, presumably due to changes in irrigation and weed control practices as well as to a shift of the citrus industry to warmer areas further south (17). Ascospore production occurs year-round and thus infection can occur at any time when conditions are favorable for spore germination and epiphytic growth.

Pseudothecia of $M$. citri are produced in densely aggregated groups mostly on the abaxial leaf surface of decomposing leaves on the grove floor. They have a papillate ostiole and are up to $90 \mu \mathrm{m}$ in diameter. Ascospores are hyaline and fusiform with a single septum and measure $2.3 \times 6.12 \mu \mathrm{m}$. Whiteside $(20)$ noted that alternate wetting and drying of detached leaves was required for pseudothecial production, but little else is known about the conditions for production of the teleomorph. The environmental requirements for production and development of ascoma in other pathogenic ascomycetes such as Venturia inaequalis, the cause of apple scab, and Didymella rabei, the cause of Ascochyta blight of chickpea, have been extensively studied and have been reviewed elsewhere $(7,10,11,18,28)$.

We investigated the time required for pseudothecial development and maturation under different conditions of moisture and temperature. We also studied pseudothecial formation and development on leaves detached monthly and placed on the grove floor to determine the role of leaves that fall at different seasons in the epidemiology of the disease.

\section{MATERIALS AND METHODS}

Collection and processing of leaves. Mature leaves of grapefruit (Citrus paradisi Macf.) severely affected by greasy spot were collected from groves that had never been treated with fungicide. 

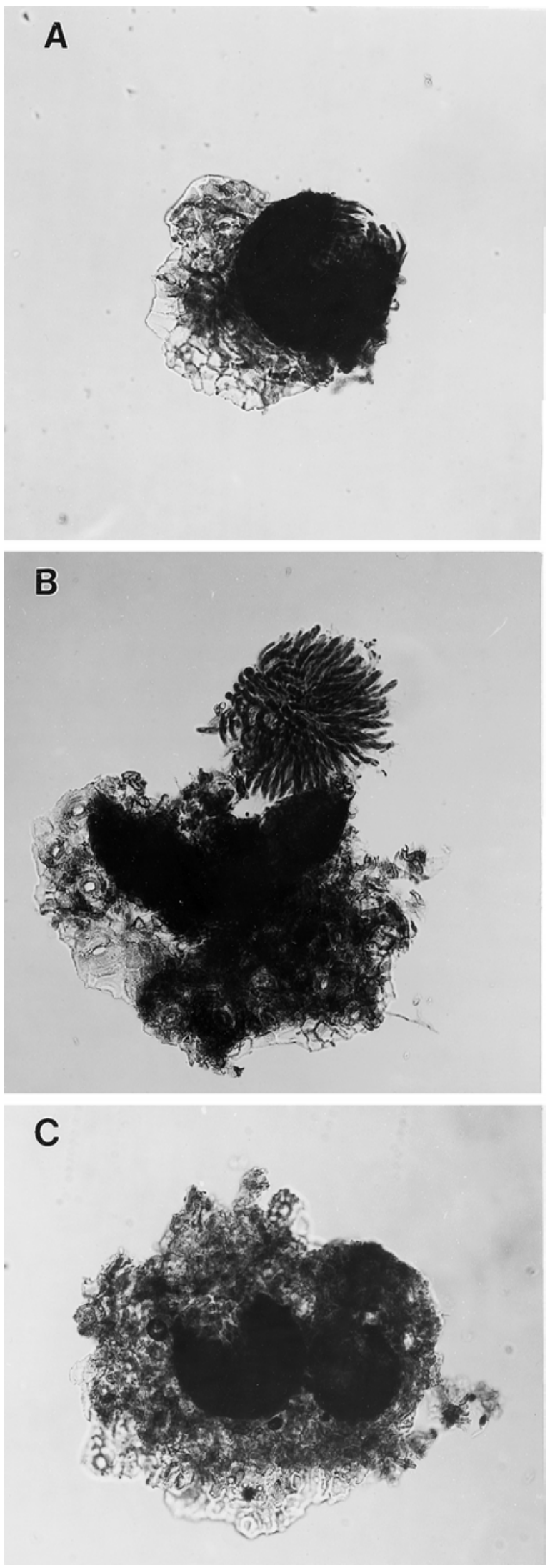

Fig. 1. Maturity classes of pseudothecia of Mycosphaerella citri in naturally infected grapefruit leaves. Pseudothecia were dissected, examined under the microscope, and classified as $\mathbf{A}$, immature $=$ no ascospores and lumen filled with only pseudoparaphyses or pseudoparaphyses and immature asci (mostly not stained) $(\times 225)$; $\mathbf{B}$, mature pseudothecia $=$ stained and septate ascospores inside asci $(\times 225)$; and $\mathbf{C}$, degenerated pseudothecia $=$ lumen of pseudothecia filled with granular globose structures and either asci- or ascosporelike structures $(\times 225)$.
Leaves were air dried in the laboratory at ambient temperature (23 to $27^{\circ} \mathrm{C}$ ) and stored dry in paper bags until used. In all experiments, a replicate consisted of three nylon mesh bags $(20 \times$ $20 \mathrm{~cm}$ ) with $1-\mathrm{mm}^{2}$ openings containing 10 to 30 leaves.

Frequency and duration of leaf soaking. In two experiments, leaves were soaked for $2 \mathrm{~h}$ a day for either $1,2,3$, or 5 days per week. Three replicate bags of 30 leaves each were used for each treatment. After soaking, leaves were air dried in the laboratory at ambient temperature. In these experiments, the number of days to produce pseudothecial initials, the percentage of leaves with pseudothecia and the density of pseudothecia, the number of days to maturity and ascospore discharge, the number of ascospores discharged, and the weight loss of leaves were measured.

In other experiments, the duration of wetting was evaluated. All treatments were soaked 4 days per week, except for the control which remained dry. Leaves were soaked for $10 \mathrm{~min}, 30 \mathrm{~min}, 1 \mathrm{~h}$, $2 \mathrm{~h}$, or $3 \mathrm{~h}$ per day and dried in the laboratory under ambient conditions between soakings. Three replicate mesh bags containing 30 leaves each were used for each treatment. The same measurements were made as in the first experiments except that days to leaf decomposition rather than leaf weight loss was measured.

Temperature effects. The effect of temperature on the production and maturation of pseudothecia and ascospore production at ambient relative humidity $(\mathrm{RH})$ and at near $100 \% \mathrm{RH}$ at each temperature was determined. For experiments at ambient RH, replicate bags of leaves were placed in incubators at 20,24, 28, and $32^{\circ} \mathrm{C}$. The ambient RHs at the different temperatures as measured by a hygrothermograph (Spectrum Technologies, Plainfield, IL) were approximately $42 \%$ at $20^{\circ} \mathrm{C}, 62 \%$ at $24^{\circ} \mathrm{C}, 71 \%$ at $28^{\circ} \mathrm{C}$, and $81 \%$ at $32^{\circ} \mathrm{C}$. Leaves were soaked for $2 \mathrm{~h}$ per day three times each week in water maintained at the same temperature. Treatments were included in which samples were alternated between 20 and $28^{\circ} \mathrm{C}$ and between 24 and $28^{\circ} \mathrm{C}$ daily to simulate differences between night and day temperatures. Leaves in these treatments were soaked every 3 days in the incubator that they were in at the time. Three replicate bags of 20 leaves each were used for each treatment.

Similar experiments were conducted at or near $100 \% \mathrm{RH}$ at temperatures of $20,24,28$, or $32^{\circ} \mathrm{C}$. Leaf samples were placed in closed plastic chambers maintained at $100 \% \mathrm{RH}$ within incubators. Leaves were maintained at $100 \% \mathrm{RH}$ continuously and in other experiments, the leaves were dried at ambient humidity in each chamber for $24 \mathrm{~h}$ every 3 days.

Pseudothecial maturation. Additional experiments were conducted using the same soaking duration treatments and the temperature treatments at ambient and at $100 \% \mathrm{RH}$. Three replicate mesh bags each containing 20 to 30 leaves were used for each treatment. Pseudothecial maturity was examined in these treatments every few days. Assessments of maturity were made microscopically when the treatments with the most advanced development had at least $50 \%$ of the pseudothecia mature, which was usually 30 to 40 days after the initiation of the experiment.

Measurements. Pseudothecial initials and maturation. The percentage of leaves with pseudothecial initials and the density of pseudothecia on leaves were observed biweekly under a dissecting microscope with epi-illumination at $\times 10$ magnification. The percentage of leaves with pseudothecia was recorded. The density was rated on a 0 to 10 scale, where $0=$ none, $1=1$ to $5 \%, 2=6$ to $10 \%, 3=11$ to $15 \%, 4=16$ to $20 \%, 5=21$ to $25 \%, 6=26$ to $30 \%, 7=31$ to $35 \%, 8=36$ to $40 \%, 9=41$ to $45 \%$, and $10=$ $>50 \%$ leaf area covered by pseudothecia. To assess pseudothecial maturity, 15 to 20 pseudothecia were dissected from the tissue in each replication, squashed in lactophenol-acid cotton blue and examined microscopically at $\times 200$ and $\times 400$ magnification as described by Gadoury and MacHardy (1). The maturity of pseudothecia was rated as immature, no ascospores and lumen of pseudothecia filled with only pseudoparaphyses or with pseudoparaphyses and immature asci (mostly not stained), mature, stained 
and septate ascospores inside asci, or degenerated, lumen of pseudothecia filled with granular globose structures and either asci- or ascospore-like structures $(1,18)$ (Fig. 1).

The days to form pseudothecial initials, to $50 \%$ maturity, and to first ascospore discharge were recorded for each replicate sample. Progress of pseudothecial formation is reported in the figures and the final density and statistical analysis in tables.
Ascospore production. Ascospores were recovered by a wooden wind tunnel apparatus modified from that described by Whiteside (23). The apparatus consisted of a wooden tray $60 \mathrm{~cm}$ long, $13 \mathrm{~cm}$ wide, and $3.5 \mathrm{~cm}$ deep. One end was tapered and had a tube through which air could be introduced from a pressurized line. The other end was tapered to a slit, $3.2 \mathrm{~mm}$ wide and $35 \mathrm{~mm}$ high, to which a glass microscope slide was attached to collect asco-

TABLE 1. Effect of the frequency and duration of leaf wetting on the production and maturation of pseudothecia and ascospore production of Mycosphaerella citri on grapefruit leaves under laboratory conditions

\begin{tabular}{|c|c|c|c|c|c|c|c|c|}
\hline $\begin{array}{l}\text { Leaf wetting }{ }^{\mathrm{t}} \\
\text { frequency or } \\
\text { duration }\end{array}$ & $\begin{array}{c}\text { Days to } \\
\text { pseudothecial } \\
\text { initials }\end{array}$ & $\begin{array}{c}\text { Days to }>50 \% \\
\text { pseudothecial } \\
\text { maturity }\end{array}$ & $\begin{array}{l}\text { Days to first } \\
\text { ascospore } \\
\text { discharge }\end{array}$ & $\begin{array}{c}\% \text { Leaf } \\
\text { weight loss }\end{array}$ & 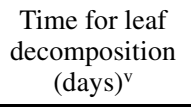 & $\begin{array}{c}\% \text { Leaves with } \\
\text { pseudothecia }\end{array}$ & $\begin{array}{l}\text { Pseudothecial } \\
\text { density } \\
(0 \text { to } 10 \text { scale })^{\mathrm{w}}\end{array}$ & $\begin{array}{c}\text { Ascospores } \\
\text { discharged per } \\
\text { leaf }\left(\times 10^{4}\right)^{\mathrm{x}} \\
\end{array}$ \\
\hline \multicolumn{9}{|l|}{ Frequency } \\
\hline 3 days/week & $27 \pm 3.5$ & $58 \pm 7.5$ & $40 \pm 10$ & $11.3 \pm 0.3$ & - & $82 \pm 4.5$ & $5.3 \pm 0.4$ & $11.7 \pm 0.6$ \\
\hline 2 days/week & $30 \pm 6.5$ & $73 \pm 1.0$ & $55 \pm 5$ & $7.4 \pm 0.2$ & - & $83 \pm 0.0$ & $2.8 \pm 0.3$ & $4.2 \pm 0.2$ \\
\hline 1 day/week & $48 \pm 9.5$ & $99 \pm 24$ & $84 \pm 27$ & $4.9 \pm 0.2$ & - & $52 \pm 1.5$ & $1.7 \pm 0.2$ & $0.7 \pm 0.1$ \\
\hline \multicolumn{9}{|l|}{ Duration } \\
\hline $1 \mathrm{~h} /$ day & $35 \pm 5.0$ & $64 \pm 6.0$ & $53 \pm 7.5$ & - & $84 \pm 6.5$ & $64 \pm 3.5$ & $2.0 \pm 0.0$ & $8.3 \pm 0.2$ \\
\hline $2 \mathrm{~h} /$ day & $28 \pm 2.5$ & $53 \pm 7.5$ & $42 \pm 3.5$ & - & $70 \pm 5.0$ & $79 \pm 8.5$ & $2.6 \pm 0.2$ & $8.3 \pm 0.1$ \\
\hline 3 h/day & $17 \pm 2.0$ & $53 \pm 7.5$ & $42 \pm 3.5$ & - & $68 \pm 7.5$ & $68 \pm 2.0$ & $1.5 \pm 0.4$ & $7.0 \pm 0.4$ \\
\hline No wetting & - & - & - & - & $>90$ & $0 \pm 0.0$ & $0.0 \pm 0.0$ & - \\
\hline
\end{tabular}

${ }^{\mathrm{t}}$ Grapefruit leaves naturally infected with $M$. citri were collected, air dried for 2 to 3 days at room temperature $\left(\approx 23\right.$ to $\left.27^{\circ} \mathrm{C}\right)$, and exposed to the various wetting regimes. In frequency experiments, leaves soaked $2 \mathrm{~h}$ per day; in duration experiments, leaves soaked four times per week.

" Pseudothecia containing asci with stained septate ascospores were considered mature.

${ }^{v}$ Leaves skeletonized and highly decomposed with no further ascospores were discharged.

${ }^{\text {w }}$ Pseudothecial density was estimated on a 0 to 10 rating scale, where $0=$ no pseudothecia and $10=>50 \%$ leaf area covered with pseudothecia.

$x$ Cumulative total for each treatment.

${ }^{y}$ Means \pm standard errors; average of two experiments (Table 4).

${ }^{\mathrm{z}}$ Not produced.

TABLE 2. The effect of temperature on pseudothecial development and ascospore production of Mycosphaerella citri in grapefruit leaves at ambient humidity

\begin{tabular}{|c|c|c|c|c|c|c|c|}
\hline Temperature $^{u}$ & $\begin{array}{c}\text { Days to } \\
\text { pseudothecial } \\
\text { initials }\end{array}$ & $\begin{array}{c}\text { Days to }>50 \% \\
\text { pseudothecial } \\
\text { maturity }\end{array}$ & $\begin{array}{l}\text { Days to first } \\
\text { ascospore } \\
\text { discharge }\end{array}$ & $\begin{array}{l}\text { Degree of leaf } \\
\text { decomposition } \\
\text { (0 to } 3)\end{array}$ & $\begin{array}{l}\text { \% Leaves with } \\
\text { pseudothecia }\end{array}$ & $\begin{array}{c}\text { Pseudothecial } \\
\text { density }(0 \text { to } 10)^{\mathrm{w}}\end{array}$ & $\begin{array}{c}\text { Ascospores } \\
\text { discharged per } \\
\text { leaf }\left(\times 10^{3}\right)\end{array}$ \\
\hline $20^{\circ} \mathrm{C}$ & $62 \pm 1.5^{y}$ & $-^{\mathrm{z}}$ & - & $1.1 \pm 0.1$ & $10 \pm 0.0$ & $0.4 \pm 0.1$ & $0.0 \pm 0.0$ \\
\hline $28^{\circ} \mathrm{C}$ & $16 \pm 1.0$ & $35 \pm 5.0$ & $30 \pm 0.0$ & $3.0 \pm 0.0$ & $90 \pm 7.5$ & $4.1 \pm 0.6$ & $20.1 \pm 2.2$ \\
\hline $32^{\circ} \mathrm{C}$ & $11 \pm 1.0$ & - & $20 \pm 0.0$ & $3.0 \pm 0.0$ & $56 \pm 4.0$ & $1.5 \pm 0.5$ & $1.3 \pm 0.7$ \\
\hline 20 to $28^{\circ} \mathrm{C}$ & $17 \pm 1.5$ & $72 \pm 1.5$ & $60 \pm 0.0$ & - & $47 \pm 6.5$ & $0.8 \pm 0.7$ & $0.4 \pm 0.0$ \\
\hline 24 to $28^{\circ} \mathrm{C}$ & $14 \pm 1.5$ & $52 \pm 1.5$ & $45 \pm 5.0$ & - & $70 \pm 3.0$ & $2.4 \pm 0.3$ & $15.6 \pm 2.9$ \\
\hline
\end{tabular}

${ }^{u}$ Grapefruit leaves naturally infected with $M$. citri were collected, air dried for 2 to 3 days at room temperature $\left(\approx 23\right.$ to $\left.27^{\circ} \mathrm{C}\right)$, and wetted and dried for $2 \mathrm{~h}$ per day and 3 days per week inside incubators held constantly at $20,24,28$, and $32^{\circ} \mathrm{C}$ or alternated daily between 20 and $28^{\circ} \mathrm{C}$, or between 24 and $28^{\circ} \mathrm{C}$ at ambient relative humidity $(\mathrm{RH})$ in each chamber: $20^{\circ} \mathrm{C}, 42 \% \mathrm{RH} ; 24^{\circ} \mathrm{C}, 62 \% \mathrm{RH} ; 28^{\circ} \mathrm{C}, 71 \% \mathrm{RH}$; and $32^{\circ} \mathrm{C}, 81 \% \mathrm{RH}$.

${ }^{v}$ Pseudothecia containing asci with stained septate ascospores were considered mature.

${ }^{\text {w }}$ Pseudothecial density was estimated on a 0 to 10 scale, where $0=$ no pseudothecia and $10=50 \%$ leaf area covered with pseudothecia.

${ }^{x}$ Cumulative totals of 10-day samplings.

${ }^{\mathrm{y}}$ Means \pm standard errors; average of two experiments (Table 4).

${ }^{\mathrm{z}}$ Not found or determined.

TABLE 3. Effect of temperature at $100 \%$ relative humidity $(\mathrm{RH})$ on the production and maturation of pseudothecia and ascospore production by Mycosphaerella citri in grapefruit leaves

\begin{tabular}{|c|c|c|c|c|c|c|c|}
\hline Temperature $^{t}$ & $\begin{array}{c}\text { Days to } \\
\text { pseudothecial } \\
\text { initials }\end{array}$ & $\begin{array}{l}\text { Days to }>50 \% \\
\text { pseudothecial } \\
\text { maturity }\end{array}$ & $\begin{array}{l}\text { Days to first } \\
\text { ascospore } \\
\text { discharge }\end{array}$ & $\begin{array}{l}\text { Days for complete } \\
\text { decomposition } \\
\text { of leaves }\end{array}$ & $\begin{array}{l}\text { \% Leaves with } \\
\text { pseudothecia }\end{array}$ & $\begin{array}{l}\text { Pseudothecial } \\
\text { density } \\
(0 \text { to } 10 \text { scale })^{\mathrm{w}}\end{array}$ & $\begin{array}{c}\text { Ascospores } \\
\text { discharged per } \\
\text { leaf }^{\mathrm{x}}\left(\times 10^{4}\right)\end{array}$ \\
\hline $20^{\circ} \mathrm{C}$ & $23 \pm 2.5^{y}$ & $-\mathrm{z}$ & $70 \pm 0.0$ & $120 \pm 0.0$ & $28 \pm 0.5$ & $0.6 \pm 0.0$ & $0.1 \pm 0.0$ \\
\hline $28^{\circ} \mathrm{C}$ & $11 \pm 1.0$ & $35 \pm 0.5$ & $29 \pm 1.5$ & $84 \pm 1.0$ & $95 \pm 5.0$ & $3.4 \pm 0.0$ & $5.5 \pm 0.3$ \\
\hline $32^{\circ} \mathrm{C}$ & $11 \pm 1.0$ & - & $25 \pm 1.0$ & $74 \pm 1.5$ & $60 \pm 3.0$ & $1.3 \pm 0.3$ & $0.4 \pm 0.0$ \\
\hline
\end{tabular}

${ }^{\mathrm{t}}$ Grapefruit leaves naturally infected with $M$. citri were collected, air dried for 2 to 3 days at room temperature $\left(\approx 23\right.$ to $\left.27^{\circ} \mathrm{C}\right)$, and incubated 3 days continuously at $100 \% \mathrm{RH}$ and interrupted by 1 day at ambient $\mathrm{RH}$ at $20,24,28$, and $32^{\circ} \mathrm{C}$.

u Pseudothecia contained asci with stained septate ascospores were considered mature.

${ }^{v}$ Leaves skeletonized and highly decomposed with no further ascospore discharge.

${ }^{\text {w }}$ Pseudothecial density was estimated on a 0 to 10 rating scale, where $0=$ no pseudothecia and $10=>50 \%$ leaf area covered with pseudothecia.

${ }^{x}$ Cumulative total of samplings about every 10 days.

y Means \pm standard errors; average of two experiments (Table 4).

${ }^{\mathrm{z}}$ Not found or not determined. 
spores. A piece of clear cellophane tape $(2 \times 4 \mathrm{~cm})$ was mounted on a microscope slide. The tape was coated with a base mixture of $10 \%$ polyvinyl alcohol in distilled water and dried for 1 to $2 \mathrm{~h}$, at which time a coat of adhesive consisting of petroleum jelly plus $10 \%$ paraffin thinned to a soft paste with toluene (3) was applied. The slide was positioned $1 \mathrm{~mm}$ from the aperture. A piece of flexible rubber tubing was affixed to the upper edge of the tray. A glass plate was placed on top of the tray and sealed with petroleum jelly. The 10 leaves for each sample were soaked for 1 $\mathrm{h}$ and placed in the tunnel with the abaxial surface facing upward. Air was passed over the sample at 10 liters/min and ascospores were collected for at least $2 \mathrm{~h}$.

Microscope slides with tapes were stained with lactophenolcotton blue and a coverslip was affixed. Slides were examined at

TABLE 4. Effect of leaf wetting duration, frequency and temperature to pseudothecial development, and ascospore production characters of Mycosphaerella citri and leaf decomposition of naturally infected grapefruit leaves under laboratory conditions

\begin{tabular}{|c|c|c|c|c|}
\hline Treatments/characters & Experiment no. & Regression equations & $R^{2}$ & $P>F$ \\
\hline \multicolumn{5}{|l|}{ Wetting frequency (wf) } \\
\hline \multicolumn{5}{|c|}{ Pseudothecial development and leaf decomposition } \\
\hline \multirow[t]{2}{*}{ Days to pseudothecial initials } & 1 & $76.77-25.35(w f)+2.68(w f)^{2}$ & 0.90 & 0.05 \\
\hline & 2 & $48.49-11.30(w f)+0.92(w f)^{2}$ & 0.99 & 0.01 \\
\hline \multirow[t]{2}{*}{ Days to $>50 \%$ pseudothecial maturity } & 1 & $168.75-55.20(w f)+6.13(w f)^{2}$ & 0.95 & 0.01 \\
\hline & 2 & $93.74-17.70(w f)+1.65(w f)^{2}$ & 0.86 & 0.05 \\
\hline \multirow[t]{2}{*}{ Days to first ascospore discharge } & 1 & $157.45-57.03(w f)+6.36(w f)^{2}$ & 0.96 & 0.01 \\
\hline & 2 & $79.05-22.32(w f)+2.47(w f)^{2}$ & 0.90 & 0.05 \\
\hline \multirow[t]{2}{*}{ Leaf decomposition by weight loss } & 1 & $1.32+3.98(w f)-0.28(w f)^{2}$ & 0.99 & 0.01 \\
\hline & 2 & $0.54+5.34(w f)-0.46(w f)^{2}$ & 0.97 & 0.01 \\
\hline \multicolumn{5}{|l|}{ Ascospore production characters } \\
\hline \multirow[t]{2}{*}{ \% Leaves with pseudothecia } & 1 & $14.48+47.79(w f)-7.62(w f)^{2}$ & 0.97 & 0.01 \\
\hline & 2 & $20.46+38.88(w f)-5.97(w f)^{2}$ & 0.77 & 0.09 \\
\hline \multirow[t]{2}{*}{ Density of pseudothecia } & 1 & $-2.45+3.58(w f)-0.52(w f)^{2}$ & 0.98 & 0.01 \\
\hline & 2 & $-1.99+2.92(w f)-0.36(w f)^{2}$ & 0.97 & 0.01 \\
\hline \multirow[t]{2}{*}{ Ascospore production } & 1 & $-14.02+16.41(w f)-2.13(w f)^{2}$ & 0.99 & 0.01 \\
\hline & 2 & $-9.94+9.48(w f)-1.08(w f)^{2}$ & 0.74 & 0.11 \\
\hline \multicolumn{5}{|l|}{ Wetting duration (wd) } \\
\hline \multicolumn{5}{|c|}{ Pseudothecial development and leaf decomposition } \\
\hline \multirow[t]{2}{*}{ Days to pseudothecial initials } & 1 & $32.58-0.14(\mathrm{wd})+0.0002(\mathrm{wd})^{2}$ & 0.97 & 0.01 \\
\hline & 2 & $50.51-0.43(\mathrm{wd})+0.001(\mathrm{wd})^{2}$ & 0.99 & 0.01 \\
\hline \multirow[t]{2}{*}{ Days to $>50 \%$ pseudothecial maturity } & 1 & $62.71-0.15(w d)+0.0003(w d)^{2}$ & 0.88 & 0.05 \\
\hline & 2 & $78.77-0.20(w d)+0.0005(w d)^{2}$ & 0.94 & 0.01 \\
\hline Days to first ascospore discharge & 1 & $50.98-0.157(w d)+0.0005(w d)^{2}$ & 0.93 & 0.01 \\
\hline & 2 & $67.8-0.23(w d)+0.0005(w d)^{2}$ & 0.91 & 0.05 \\
\hline Days for leaf decomposition & 1 & $94.52-0.33(\mathrm{wd})+0.0008(\mathrm{wd})^{2}$ & 0.99 & 0.01 \\
\hline & 2 & $103.46-0.33(w d)+0.0009(w d)^{2}$ & 0.96 & 0.01 \\
\hline Ascospore production characters & & & & \\
\hline \% Leaves with pseudothecia & 1 & $80.26-0.17(w d)+0.0008(w d)^{2}$ & 0.04 & 0.87 \\
\hline & 2 & $93.26-0.36(\mathrm{wd})+0.001(\mathrm{wd})^{2}$ & 0.83 & 0.05 \\
\hline Density of pseudothecia & 1 & $4.56-0.0 .35(w d)+0.0001(w d)^{2}$ & 0.65 & 0.17 \\
\hline & 2 & $4.03-0.028(w d)+0.0001(w d)^{2}$ & 0.76 & 0.09 \\
\hline Ascospore production & 1 & $12.83-0.068(\mathrm{wd})+0.0002(\mathrm{wd})^{2}$ & 0.93 & 0.01 \\
\hline & 2 & $13.14-0.08(w d)+0.0003(w d)^{2}$ & 0.81 & 0.05 \\
\hline Temperature at ambient relative humidit & & & & \\
\hline Pseudothecial development and leaf dec & & & & \\
\hline Days to pseudothecial initials & 1 & $470.23-31.00($ Temp $)+0.52(\text { Temp })^{2}$ & 0.97 & 0.01 \\
\hline & 2 & $435.95-27.72($ Temp $)+0.45(\text { Temp })^{2}$ & 0.99 & 0.01 \\
\hline Days to first ascospore discharge & 1 & $1,308.0-86.2($ Temp $)-1.43(\text { Temp })^{2}$ & 0.99 & 0.01 \\
\hline & 2 & $940.0-58.75($ Temp $)+0.93(\text { Temp })^{2}$ & 0.99 & 0.01 \\
\hline Degree of decomposition & 1 & $-9.68+0.78($ Temp $)-0.012(\text { Temp })^{2}$ & 0.96 & 0.01 \\
\hline & 2 & $-9.08+0.69($ Temp $)-0.009(\text { Temp })^{2}$ & 0.92 & 0.01 \\
\hline Ascospore production characters & & & & \\
\hline$\%$ Leaves with pseudothecia & 1 & $-1,192.7+96.22($ Temp $)-1.79(\text { Temp })^{2}$ & 0.92 & 0.01 \\
\hline & 2 & $-1,077.6+85.57($ Temp $)-1.56(\text { Temp })^{2}$ & 0.99 & 0.01 \\
\hline Density of pseudothecia & 1 & $-41.87+3.34($ Temp $)-0.06(\text { Temp })^{2}$ & 0.75 & 0.11 \\
\hline & 2 & $-43.61+3.48($ Temp $)-0.06(\text { Temp })^{2}$ & 0.95 & 0.01 \\
\hline Ascospore production & 1 & $-220.87+17.30(\mathrm{Temp})-0.32(\mathrm{Temp})^{2}$ & 0.41 & 0.69 \\
\hline & 2 & $-171.93+13.44(\mathrm{Temp})-0.24(\mathrm{Temp})^{2}$ & 0.41 & 0.69 \\
\hline Temperature at $100 \%$ relative humidity & & & & \\
\hline Pseudothecial development and leaf dec & & & & \\
\hline Days to pseudothecial initials & 1 & $87.75-4.97($ Temp $)+0.07(\text { Temp })^{2}$ & 0.98 & 0.01 \\
\hline & 2 & $145.80-9.15($ Temp $)+0.15(\text { Temp })^{2}$ & 0.99 & 0.01 \\
\hline Days to first ascospore discharge & 1 & $318.08-19.14($ Temp $)+0.31(\text { Temp })^{2}$ & 0.99 & 0.01 \\
\hline & 2 & $363.70-21.57($ Temp $)+0.34(\text { Temp })^{2}$ & 0.99 & 0.01 \\
\hline Days for leaf decomposition & 1 & $381.0-6.05(\mathrm{Temp})+0.15(\mathrm{Temp})^{2}$ & 0.99 & 0.01 \\
\hline & 2 & $307.78-12.88(\mathrm{Temp})+0.17(\mathrm{Temp})^{2}$ & 0.99 & 0.01 \\
\hline Ascospore production characters & & & & \\
\hline$\%$ Leaves with pseudothecia & 1 & $-796.4+65.03($ Temp $)-1.19(\text { Temp })^{2}$ & 0.97 & 0.01 \\
\hline & 2 & $-981.18+80.15($ Temp $)-1.48(\text { Temp })^{2}$ & 0.99 & 0.01 \\
\hline Density of pseudothecia & 1 & $-48.72+3.97($ Temp $)-0.07(\text { Temp })^{2}$ & 0.99 & 0.01 \\
\hline & 2 & $-48.42+3.95($ Temp $)-0.07(\text { Temp })^{2}$ & 0.99 & 0.01 \\
\hline Ascospore production & 1 & $-78.69+6.30($ Temp $)-0.11(\text { Temp })^{2}$ & 0.77 & 0.78 \\
\hline & 2 & $-80.80+6.47(\mathrm{Temp})-0.12(\mathrm{Temp})^{2}$ & 0.87 & 0.05 \\
\hline
\end{tabular}


$\times 400$ magnification. Ascospores in 10 microscope fields selected arbitrarily were counted, and the average number of spores per slide was calculated. Data are presented as the average number of ascospores per leaf. Ascospore discharge was determined at 7- to 10-day intervals throughout the duration of each experiment. The ascospore discharge pattern and cumulative ascospore recovery are presented in the figures. Data presented in tables are the cumulative total of all samplings in each treatment.

Leaf decomposition. In some experiments, leaf decomposition was evaluated by weighing the leaves after drying under laboratory conditions during the course of the experiment. The degree of breakdown was also estimated on a scale of 0 to 3 , where $0=$ not decomposed, still firm; 1 = partially decomposed, flexible still intact; 2 = moderately decomposed, some loss of lamina; and $3=$ highly decomposed, skeletonized leaves. In some cases, results are presented as the number of days to reach stage three or progress of decomposition with time.

Analysis of data from laboratory experiments. All of the wetting frequency and duration treatments as well as the temperature treatments were repeated once. Because these were quantitative variables, regression analyses were used to determine the effect of each on the many factors studied. In the case of the temperature treatments, only those maintained at constant temperatures were included in the regression analyses. The means \pm the standard errors of the two experiments are presented in Table 1 for the effects of moisture and in Tables 2 and 3 for the effects of temperature. For most factors studied, there was no significant effect of experiment nor was there a significant experiment-treatment

TABLE 5. Influence of moisture and temperature on maturation of pseudothecia of Mycosphaerella citri in naturally infected grapefruit leaves

\begin{tabular}{|c|c|c|c|}
\hline \multirow[b]{2}{*}{ Treatments $^{\mathrm{u}}$} & \multicolumn{3}{|c|}{ Pseudothecial groups $(\%)^{\mathrm{v}}$} \\
\hline & Immature & Mature & Degenerated \\
\hline \multicolumn{4}{|c|}{ Soaking duration ${ }^{\mathrm{w}}$} \\
\hline $10 \mathrm{~min} /$ day & $8 \pm 4.0^{x}$ & $92 \pm 4.0$ & $0.0 \pm 0.0$ \\
\hline $30 \mathrm{~min} /$ day & $6 \pm 6.0$ & $88 \pm 6.6$ & $6 \pm 6.0$ \\
\hline $1 \mathrm{~h} /$ day & $0.0 \pm 0.0$ & $72 \pm 3.0$ & $28 \pm 3.0$ \\
\hline $2 \mathrm{~h} /$ day & $0.0 \pm 0.0$ & $50 \pm 3.0$ & $50 \pm 3.5$ \\
\hline $3 \mathrm{~h} /$ day & $0.0 \pm 0.0$ & $40 \pm 7.5$ & $60 \pm 7.5$ \\
\hline \multicolumn{4}{|c|}{ Temperature at ambient $\mathrm{RH}^{\mathrm{y}}$} \\
\hline $20^{\circ} \mathrm{C}$ & $100 \pm 0.0$ & $0.0 \pm 0.0$ & $0.0 \pm 0.0$ \\
\hline $24^{\circ} \mathrm{C}$ & $68 \pm 3.0$ & $32 \pm 1.0$ & $0.0 \pm 0.0$ \\
\hline $28^{\circ} \mathrm{C}$ & $0.0 \pm 0.0$ & $92 \pm 0.5$ & $8 \pm 0.5$ \\
\hline $32^{\circ} \mathrm{C}$ & $0.0 \pm 0.0$ & $14 \pm 2.5$ & $86 \pm 2.5$ \\
\hline 20 to $28^{\circ} \mathrm{C}$ & $65 \pm 4.5$ & $32 \pm 5.0$ & $3 \pm 0.5$ \\
\hline 24 to $28^{\circ} \mathrm{C}$ & $18 \pm 7.5$ & $82 \pm 7.5$ & $0.0 \pm 0.0$ \\
\hline \multicolumn{4}{|c|}{ Temperature at $100 \% \mathrm{RH}^{\mathrm{z}}$} \\
\hline $20^{\circ} \mathrm{C}$ & $100 \pm 0.0$ & $0.0 \pm 0.0$ & $0.0 \pm 0.0$ \\
\hline $24^{\circ} \mathrm{C}$ & $32 \pm 1.0$ & $68 \pm 5.0$ & $0.0 \pm 0.0$ \\
\hline $28^{\circ} \mathrm{C}$ & $18 \pm 9.5$ & $82 \pm 6.0$ & $0.0 \pm 0.0$ \\
\hline $32^{\circ} \mathrm{C}$ & $0.0 \pm 0.0$ & $7 \pm 7.0$ & $93 \pm 6.0$ \\
\hline
\end{tabular}

u Grapefruit leaves naturally infected with $M$. citri were collected and air dried for 2 to 3 days under room temperature $\left(\approx 23\right.$ to $\left.25^{\circ} \mathrm{C}\right)$.

${ }^{v}$ For each treatment, 15 to 20 pseudothecia were dissected from the tissue, squashed in lacto-phenol-acid cotton blue, and examined microscopically. The pseudothecia were grouped as immature, no ascospores and lumen of pseudothecia filled with only pseudoparaphyses or with pseudoparaphyses and immature asci (mostly not stained), mature, stained and septate ascospores inside asci, and degenerated, lumen of pseudothecia with granular globose structures and either asci- or ascospore-like structures.

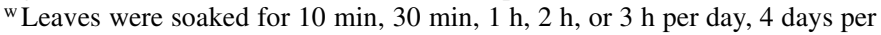
week, under laboratory conditions.

${ }^{x}$ Each value is the mean of two experiments with three replicates each \pm standard error.

${ }^{y}$ Leaves were wetted for $2 \mathrm{~h}$ per day and 3 days per week inside incubators maintained constantly at $20,24,28$, or $32^{\circ} \mathrm{C}$ or alternated daily between 20 and $28^{\circ} \mathrm{C}$ or between 24 and $28^{\circ} \mathrm{C}$ at ambient humidity in each chamber: $20^{\circ} \mathrm{C}, 42 \%$ relative humidity (RH); $24^{\circ} \mathrm{C}, 62 \% \mathrm{RH} ; 28^{\circ} \mathrm{C}, 71 \% \mathrm{RH}$; and $32^{\circ} \mathrm{C}, 81 \% \mathrm{RH}$.

${ }^{\mathrm{z}}$ Leaves were incubated inside humid chambers near $100 \% \mathrm{RH}$ at 20,24 , 28 , and $32^{\circ} \mathrm{C}$ for 3 days, dried for 1 day, and the cycle repeated.
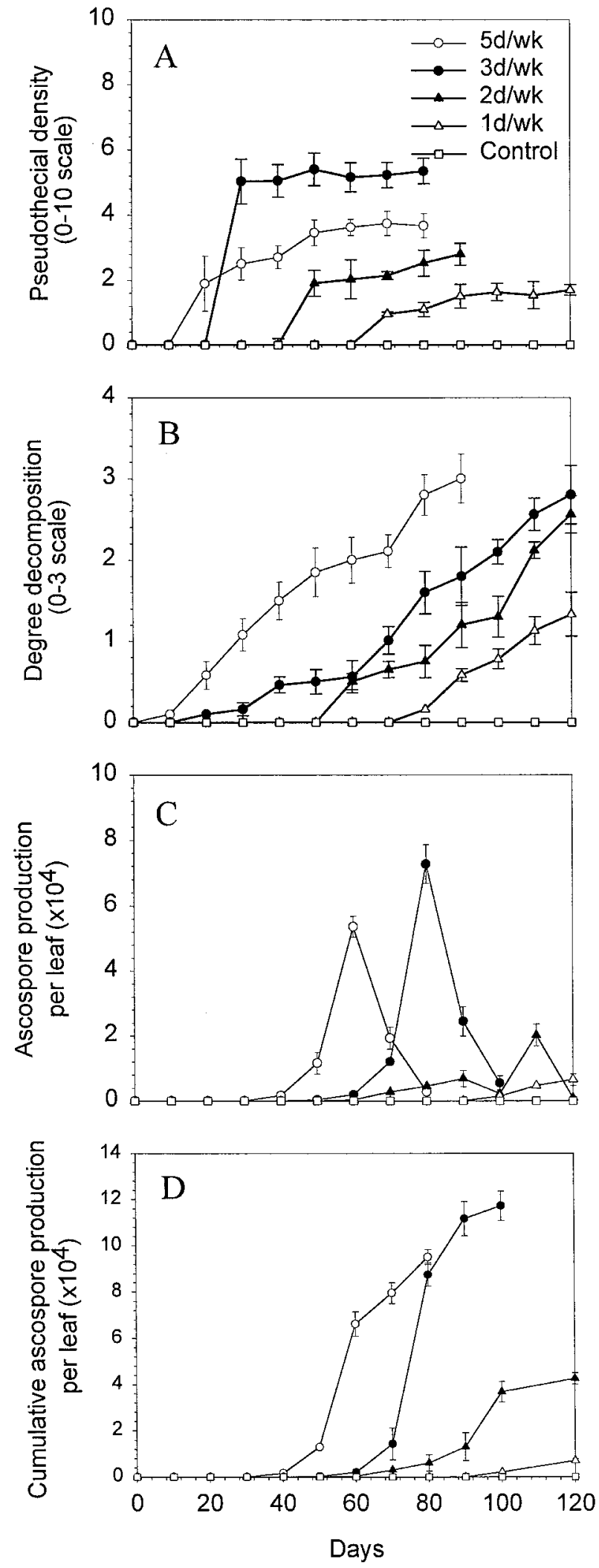

Fig. 2. Effects of leaf wetting and drying on the pattern of pseudothecia development and discharge of ascospores of Mycosphaerella citri and degree leaf decomposition. A, Pseudothecial density measured on a 0 to 10 scale, where $0=$ no pseudothecia and $10=>50 \%$ of the leaf area covered with pseudothecia. B, Degree of leaf decomposition measured on a 0 to 3 scale, where $0=$ undecomposed leaf without pseudothecia and $3=$ highly decomposed and skeletonized leaves with no further ascospore discharge. C, Ascospore discharge at 10-day intervals, no ascospores discharged from control leaves. D, Cumulative discharge of ascospores recorded at 10-day intervals. Each point is the mean of two experiments with three replicates each \pm standard error. 

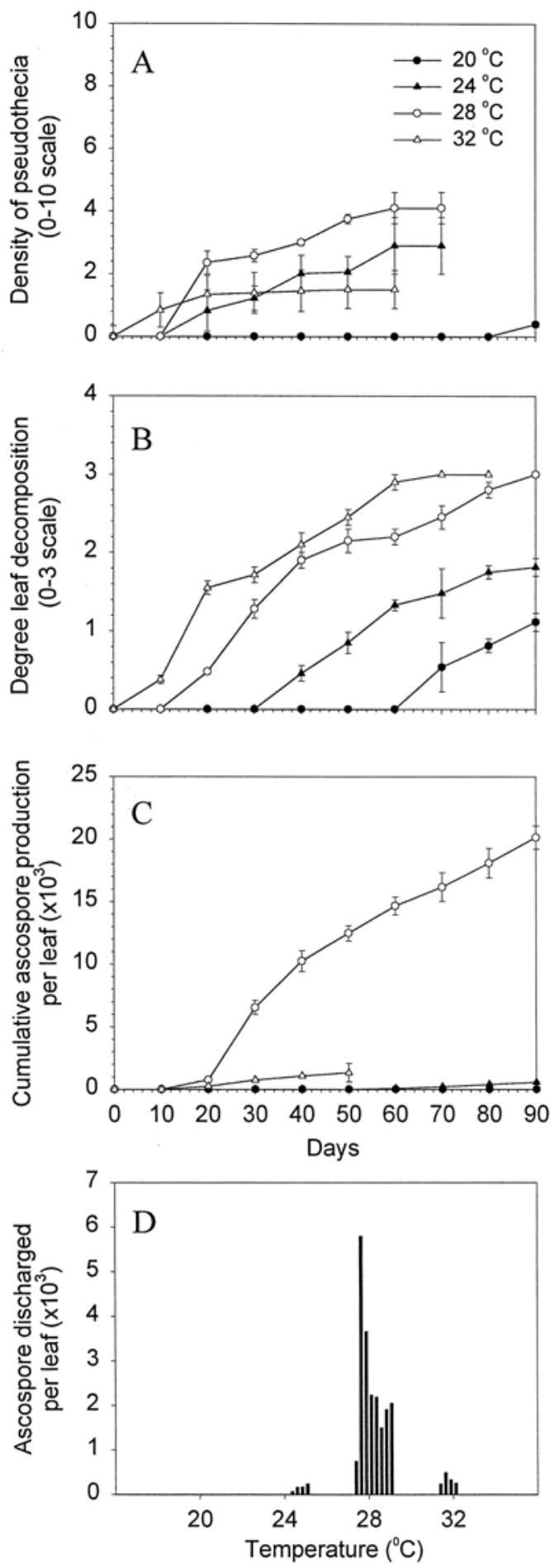

Fig. 3. The effect of temperature on the pattern of development of pseudothecia, leaf decomposition, and production of ascospores of Mycosphaerella citri in naturally infected grapefruit leaves after wetting and drying. Leaves were wetted for $2 \mathrm{~h}$ per day and 3 days per week in incubators held at constant temperature and at ambient relative humidity (RH) for each temperature: $20^{\circ} \mathrm{C}, 42 \% \mathrm{RH} ; 24^{\circ} \mathrm{C}, 62 \% \mathrm{RH} ; 28^{\circ} \mathrm{C}, 71 \% \mathrm{RH}$; and $28^{\circ} \mathrm{C}, 81 \%$ RH. A, Density of pseudothecia measured on a 0 to 10 scale, where $0=$ no pseudothecia and $10=>50 \%$ of the leaf area covered with pseudothecia. $\mathbf{B}$, Degree of leaf decomposition measured on a 0 to 3 scale, where $0=$ undecomposed leaves without pseudothecia and $3=$ highly decomposed, skeletonized leaves with no further ascospore discharge. C, Cumulative discharge of ascospores at 10-day intervals. Each point in the line graph is the mean of two experiments with three replicates each \pm standard error. D, Pattern of ascospores discharged at 10-day intervals. Each bar represents total ascospores discharged at each sampling time and is the mean of three replicates \pm standard error. interaction. However, because differences occurred with some factors in some experiments, regression equations were developed separately for each factor and each experiment and are presented in Table 4.

Two experiments were conducted to assess the effect of moisture and temperature on the maturity of pseudothecia. Analysis of variance indicated no significant effect of experiment or significant experiment-treatment interactions. The means \pm the standard deviations averaged across both experiments are presented in Table 5.

Field study. Six mesh bags of 10 leaves each were placed on the floor of a grapefruit grove monthly from April 2000 until September 2001. Leaves were exposed to ambient temperature and rainfall in the grove. Weather data were collected at a station within $500 \mathrm{~m}$ of the experimental site. Trees in the grove were irrigated by microsprinkler irrigation and received approximately $17 \mathrm{~mm}$ each time and were irrigated up to three times per week when no rainfall occurred. Leaf samples were examined weekly to determine the status of pseudothecial development and leaf decomposition and returned to the grove. The number of days to first production of pseudothecial initials, mature pseudothecia, first ascospore release, and leaf decomposition was recorded for each monthly sample. The percentage of leaves with pseudothecia and the pseudothecial density were recorded at 30, 45, and 60 days after placement of the leaf samples. The data presented for each monthly sample is the average of the three samplings, except where leaves decomposed before 60 days. Ascospore release was determined at 10-day intervals after first release of ascospores. Data presented are the cumulative total number of all of the ascospores collected from each sampling date. Temperatures presented are the averages for each 2 -week period. Rainfall and irrigation are presented as the totals for each 2-week period.

Linear regression analysis was conducted to relate all of the variables measured to the total rainfall and average temperature. In each case, the period selected for weather data was from the beginning of the experiment until the date of evaluation regardless of the length of the period. For example, temperature or rainfall was regressed against the days to pseudothecial initials using the average temperature or total rainfall from day 0 to formation which may have been 20 days in some months and 30 in others.

\section{RESULTS}

Frequency and duration of leaf soaking. Pseudothecial development, i.e., the number of days to produce pseudothecial initials, the days to $50 \%$ pseudothecial maturity, and the days to first ascospore discharge, was shortest when leaves were soaked 5 days per week (Table 1). The wetting frequency and all development factors were significantly related to the rate of development, increasing as the wetting frequency increased (Table 4). However, the percentage of leaves with pseudothecia, the pseudothecial density, and the total number of ascospores recovered were higher when leaves were soaked three times per week (Table 1; Fig. 2). Pseudothecia were produced later and in lower numbers and ascospore discharge was less when leaves were soaked only 1 or 2 days per week (Fig. 2). The percentage of leaves with pseudothecia, the density of pseudothecia, and ascospore production were significantly related to wetting duration in both experiments. The percent weight loss of leaves was greatest when leaves were soaked 5 days per week. Control leaves which were not wetted did not develop pseudothecia.

Soaking duration also affected pseudothecial production, maturation, and ascospore production. The number of days to produce pseudothecial initials, to achieve 50\% maturity, and to first ascospore release was lowest when leaves were soaked for 2 to $3 \mathrm{~h}$ (Table 1). Progress of development increased significantly as wetting duration increased (Table 4). However, the percentage of the leaves with pseudothecia, the density, and the total number of 
ascospores discharged tended to be lower as wetting duration increased. However, this relationship was not significant in all cases (Table 4). The rate of decomposition increased significantly with increased durations of wetting (Table 4). Thus, longer durations of wetting accelerated the process of pseudothecial maturation and leaf decomposition, but maximum production was achieved with shorter durations of wetting.

Effect of temperature. In leaves soaked $2 \mathrm{~h}$ per day, three times per week, and held at ambient $\mathrm{RH}$, development of pseudothecia was most rapid at 28 or $32^{\circ} \mathrm{C}$ (Table 2; Fig. 3). The days to pseudothecial initials and to first ascospore discharge were significantly related to temperature (Table 4). The percentage of leaves with pseudothecia and pseudothecial density were highest at $28^{\circ} \mathrm{C}$ (Table 2) and significantly related to temperature in most cases (Table 4). Ascospore production was clearly highest at $28^{\circ} \mathrm{C}$ or when leaves were alternated between 24 and $28^{\circ} \mathrm{C}$. Neither polynomial regressions nor any other types of relationships tested provided a significant fit to these data. This was probably due to the fact that most of the values at temperatures other than $28^{\circ} \mathrm{C}$ were near 0 (Table 2; Fig. 3D). Leaf decomposition was related significantly to temperature (Table 4).

Leaves that were soaked and maintained continually at $100 \%$ $\mathrm{RH}$ and $20,24,28$, and $32^{\circ} \mathrm{C}$ decayed quickly and were colonized by saprophytic fungi. Pseudothecia were formed within 10 days at $100 \% \mathrm{RH}$ regardless of temperature. However, pseudothecia did not mature and degenerated and no ascospores were discharged (data not shown). However, when leaves were allowed to dry for 1 day following 3 days at $100 \% \mathrm{RH}$, results were similar to those in the previous experiments. The time to pseudothecial formation and ascospore release was shortest at 28 or $32^{\circ} \mathrm{C}$ (Table 3; Fig. 4) and significantly related to temperature (Table 4). Pseudothecial production and total ascospore release was greatest at 24 or $28^{\circ} \mathrm{C}$ and significantly related to temperature in most cases (Table 4). Development was slowed greatly and no ascospores were released at $20^{\circ} \mathrm{C}$. Leaf decomposition was most rapid at $32^{\circ} \mathrm{C}$ (Table 3 ) and significantly related to temperature in both experiments (Table 4).

Pseudothecial maturation. The development and maturation of pseudothecia under the various moisture and temperature conditions was followed more closely in separate experiments. In the soaking duration experiments, many of the pseudothecia had already degenerated by 30 to 40 days after initiation of the experiment when leaves were soaked 2 to $3 \mathrm{~h}$ per day (Table 5). At the same time, however, most of the pseudothecia in leaves that had been soaked for 10 to $30 \mathrm{~min}$ per day and 4 days per week were mature. In both of the temperature experiments, the highest percentage of the pseudothecia was mature at $28^{\circ} \mathrm{C}$ at 30 to 40 days after initiation of the experiment regardless of the ambient humidity. Thus, soaking leaves for 10 to $30 \mathrm{~min}$, three to four times per week, and holding leaves at $28^{\circ} \mathrm{C}$ produced the maximum number of mature pseudothecia.

Field studies. The time required for production of pseudothecial initials, for pseudothecial maturation, for first ascospore release, and for decomposition of leaves was shorter in the summer months, from June to September, than during other periods of the year (Fig. 5). Leaves placed on the grove floor from October to May eventually produced high densities of pseudothecia and large numbers of ascospores. Those placed on the grove floor in the summer decomposed quickly and produced few pseudothecia and ascospores (Fig. 5). The high temperature and rainfall during the summer (Fig. 5) appeared to favor rapid leaf decomposition.

In the field, temperature was a significant factor and explained from 27 to $64 \%$ of the variability in all pseudothecial development characters except for ascospore production (Table 6). Total precipitation, rainfall plus irrigation, was not highly related to any of the development or production characters. The total amount of moisture applied over the different periods (Fig. 5) was too uniform to produce highly significant effects on pseudothecial development, ascospore production, or leaf decomposition.

\section{DISCUSSION}

High moisture levels are needed for formation, development, and maturation of pseudothecia of $M$. citri, but intermittent drying is also essential. Moisture is the limiting factor for the formation of ascomata initials in infected plant tissue by other plant pathogenic members of the Ascomycotina $(5,6,13,18)$. A continuous supply of moisture is required for pseudothecial formation and maturation of $V$. inaequalis in naturally infected apple leaves (5) and of $D$. rabei in chickpea straw (18). In contrast, occasional drying of citrus leaves appears to be necessary for formation of pseudothecia of $M$. citri. Leaves maintained under constant moisture appear to be colonized by many saprophytic organisms that may compete with $M$. citri for available nutrients or be antagonistic to the pathogen. Even if pseudothecia are produced, they fail to produce ascospores.

The optimum temperature for the formation and development of pseudothecia of $M$. citri, $28^{\circ} \mathrm{C}$, corresponds well with the optimum temperature for ascospore germination and germ tube growth reported by Whiteside (24). Many plant pathogenic ascomycetes like $V$. inaequalis, the cause of apple scab, D. rabei, the cause of Ascochyta blight of chickpea, and Pyrenopeziza brassicae, the cause of light leaf spot of canola, have much lower opti-
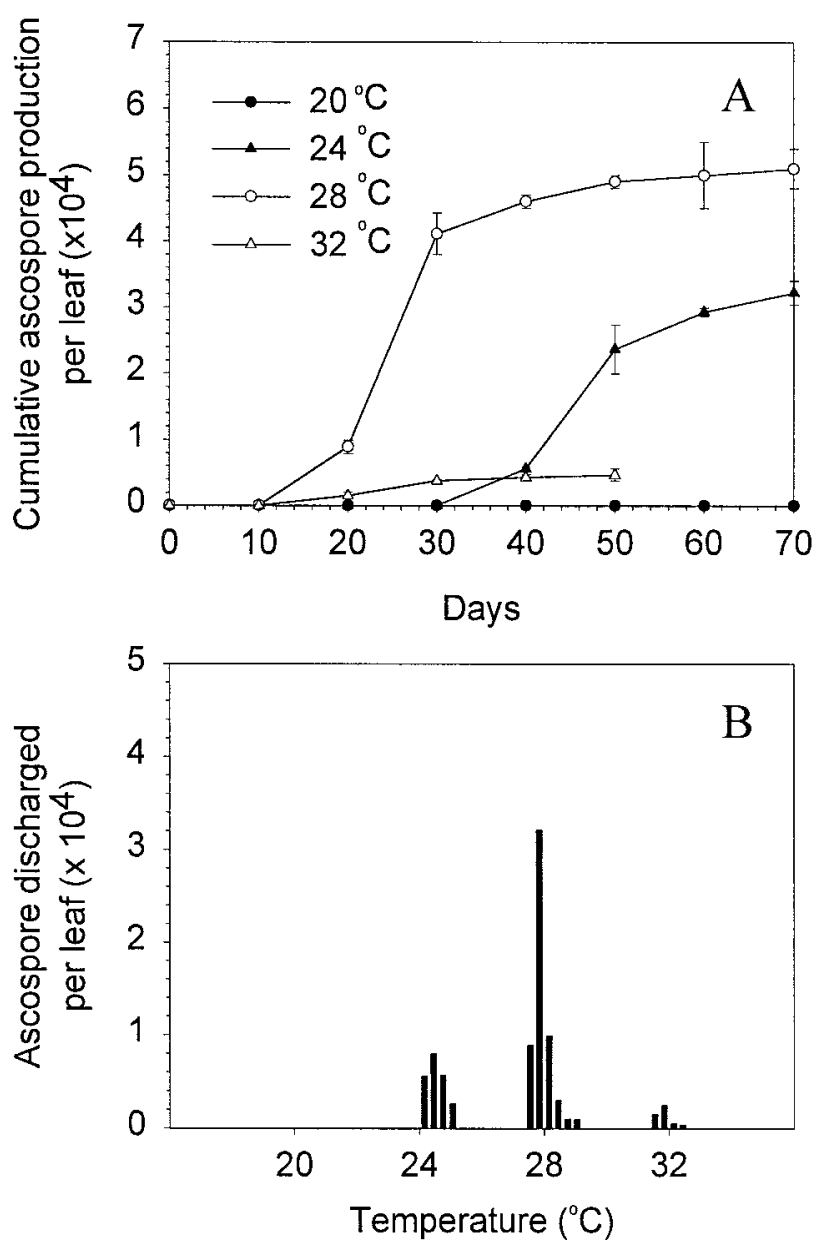

Fig. 4. Effect of different temperatures on ascospore production of Mycosphaerella citri in grapefruit leaves held at a constant $100 \%$ relative humidity (RH). Grapefruit leaves naturally infected with $M$. citri were collected, air dried for 2 to 3 days at room temperature $\left(\approx 23\right.$ to $\left.25^{\circ} \mathrm{C}\right)$, incubated 3 days continuously at $100 \% \mathrm{RH}$, and interrupted by 1 day of drying at ambient $\mathrm{RH}$ at $20,24,28$, and $32^{\circ} \mathrm{C}$. A, Cumulative ascospore production, and $\mathbf{B}$, pattern of ascospore production. Each bar indicates the number of ascospores recovered at different sample times. Each point is the mean of two experiments of three replicates each \pm standard error of ascospores discharged at 10-day intervals. 

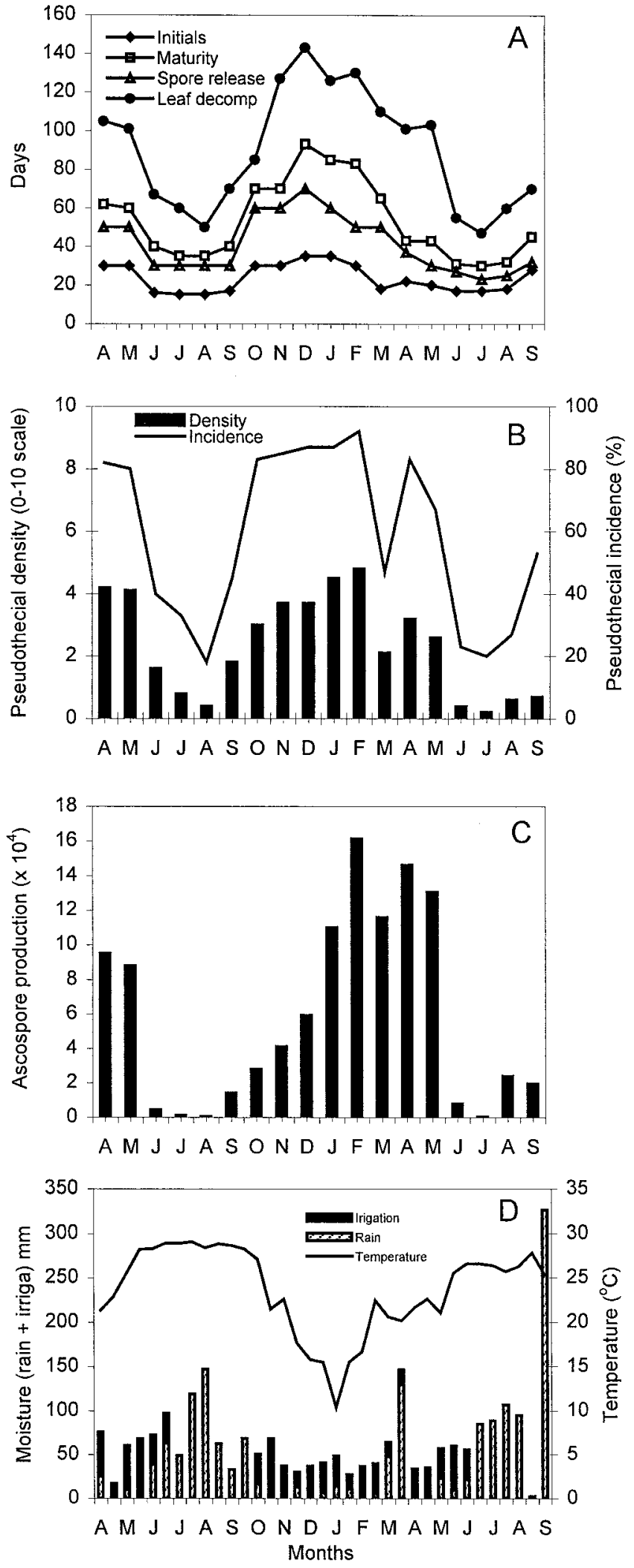

2000

2001

Fig. 5. Relationship between rainfall and temperature and pseudothecia production, maturation, and ascospore production of Mycosphaerella citri in naturally infected grapefruit leaves placed on the grove floor at monthly intervals. Months indicate the date when leaves were placed in the grove. A, Days required for first production of pseudothecial initials, 50\% maturity of pseudothecia, first ascospore release, and complete decomposition of leaves. $\mathbf{B}$, Incidence and density of pseudothecia. $\mathbf{C}$, Total ascospore production from leaves. D, Biweekly rainfall and irrigation totals and average temperature. mum temperatures for ascoma production and development $(2,9$, 12,13,18). However, these are all pathogens of temperate crops and their sexual stages often develop very early in spring under low temperatures. Pathogens of more tropical crops such as $M$. fijiensis, the cause of Black Sigatoka of banana, or D. liguicola, the cause of blight of chrysanthemum, have much higher temperature optima $(8,19)$. Thus, $M$. citri appears to be well adapted to citrus and the conditions under which the crop is grown in subtropical and tropical areas.

Laboratory research on the conditions for pseudothecial development has defined clearly the optimum temperature, moisture conditions, and time for production of pseudothecia. This should greatly facilitate further research on the conditions needed for ascospore release, on the ontogeny of pseudothecial development, and on management practices to prevent production of pseudothecia.

The results of field studies corresponded closely with the results from the laboratory. Rainfall and temperature appeared to affect most of the characters related to pseudothecial development. Temperature was a highly significant factor, but moisture could not be evaluated because irrigation made the amount of precipitation to which samples were exposed too similar. Total ascospore release was not related to temperature within the ranges of this experiment. The lack of a relationship with moisture may also be attributable to the fact that small amounts of rain trigger as much release of ascospores as larger amounts (S. N. Mondal, T. R. Gottwald, and L. W. Timmer, unpublished data). Total ascospore release from a given set of leaves held at lower temperatures may be the same as at higher temperatures, but release may occur over a longer period.

The rapid decomposition of leaves without production of pseudothecia suggests that regulating moisture may help to reduce the inoculum load. It is also conceivable that saprophytes or nutrients could be added to accelerate the decomposition of leaf litter and reduce inoculum production.

In Florida, the number of ascospores trapped in citrus groves is always low in middle to late summer $(17,20)$. This has been attributed to the fact that the leaves dropped in February to March are completely decomposed by the middle of July. However, it is also probably due to the rapid decomposition and lack of ascospore production on leaves that fall during the summer.

The environmental conditions required for pseudothecial formation help to explain the time of peak ascospore release under different management practices. In previous years in Florida, leaf drop occurred in late winter and early spring (February to March) (20). However, due to low rainfall in April to May, leaf litter did not decompose. Irrigation was provided by overhead sprinkler and water was applied only every 2 to 3 weeks. Ascospores were not released until the beginning of the summer rains in June to July (20). Currently, with microsprinkler irrigation, groves are watered two to three times per week in spring and ascospore peaks now

TABLE 6. Linear regression analysis of the relationship of temperature on the production and maturation of pseudothecia and ascospore production of Mycosphaerella citri and decomposition of grapefruit leaves in the field study

\begin{tabular}{lll}
\hline & \multicolumn{2}{c}{ Temperature } \\
Character & \multicolumn{1}{c}{$R^{2}$} & Slope \\
\hline Pseudothecial development and leaf decomposition & & \\
Days to pseudothecial initials & $0.45^{* *}$ & $-1.0^{* *}$ \\
Days to 50\% pseudothecial maturity & $0.56^{* * *}$ & $-3.5^{* * *}$ \\
Days to first ascospore discharge & $0.64^{* * *}$ & $-2.6^{* *}$ \\
Days to leaf decomposition & $0.32^{*}$ & $-4.4^{*}$ \\
Ascospore production characters & & \\
\% Leaves with pseudothecia & $0.40^{* *}$ & $-3.8^{* *}$ \\
Density of pseudothecia & $0.27^{*}$ & $-0.2^{*}$ \\
Ascospore production & $0.03^{\mathrm{NS}}$ & $-0.3^{\mathrm{NS}}$ \\
\hline
\end{tabular}

${ }^{\mathrm{z}} R^{2}=$ coefficient of determination for the model. *,**, and $* * *$ indicate significance at $P \leq 0.05,0.01$, or 0.001 , respectively. NS $=$ not significant. 
occur in April to May (17). In Texas, which has a semiarid climate, very little rainfall occurs following leaf drop in early spring. Groves are often flood-irrigated, offering infrequent opportunity for wetting of leaves. In that area, peak ascospore release is in August to September after the summer rains begin (16). In Costa Rica, groves are not irrigated. Most of the leaf drop occurs in dry periods from March to May. Pseudothecia development and ascospore production occur only after the summer rains which begin in June to July (4).

Definition of the conditions for the production and maturation of ascospores may now allow accurate prediction of peak ascospore release. Whiteside (24) found that periods of infection corresponded well with peaks in ascospore production. Thus, it would appear that this information would be useful in timing fungicide applications. However, in more recent years, when the peaks in ascospore production shifted to April to May, the primary infection period remained in the June to September rainy season (15). Thus, Whiteside's observations may have been due to coincidental correspondence of the ascospore peak and good conditions for epiphytic mycelial growth and infection. It now appears that the amount of infection corresponds more closely with the conditions for development of $M$. citri on the leaf surface than with the number of ascospores present (15).

The other mitigating factor is that although leaf drop occurs generally in January to March, some leaf drop occurs year-round. Thus, some ascospores are available throughout the year. Infection may occur at any time that conditions of temperature and leaf moisture on the leaf surface are adequate. It may be necessary to protect all major flushes of leaves as they emerge throughout the season for adequate control of greasy spot rather than apply single sprays to control disease only on spring growth $(22,27)$.

\section{ACKNOWLEDGMENTS}

This research was supported by the Florida Agricultural Experiment Station and a grant from the Florida Citrus Production Research Advisory Council, Projects 991-36P and 013-16P, and approved for publication as Journal Series No. R-08731. We thank L. Zhang for excellent technical assistance and R. H. Brlansky for assistance with photography.

\section{LITERATURE CITED}

1. Gadoury, D. M., and MacHardy, W. E. 1982. Preparation and interpretation of squash mounts of pseudothecia of Venturia inaequalis. Phytopathology 72:92-95.

2. Gilles, T., Fitt, B. D. L., and Jeger, M. J. 2001. Effects of environmental factors on the development of Pyrenopeziza brassicae (light leaf spot) apothecia on oilseed rape debris. Phytopathology 91:392-398.

3. Gottwald, T. R., Trocine, T. M., and Timmer, L. W. 1997. A computercontrolled environmental chamber for the study of aerial fungal spore release. Phytopathology 87:1078-1084.

4. Hidalgo, H., Sutton, T. B., and Arauz, F. 1997. Epidemiology and control of citrus greasy spot on Valencia orange in the humid tropics of Costa Rica. Plant Dis. 81:1015-1022.

5. James, J. R., and Sutton, T. R. 1982. Environmental factors influencing pseudothecial development and ascospore maturation of Venturia inaequalis. Phytopathology 72:1073-1080.

6. Lee, Y. S., and Huang, C. S. 1973. Effect of climatic factors on the development and discharge of ascospores of citrus black spot fungus. J.
Taiwan Agric. Res. 22:135-144.

7. MacHardy, W. E., Gadoury, D. M., and Gessler, C. 2001. Parasitic and biological fitness of Venturia inaequalis: Relationship to disease management strategies. Plant Dis. 85:1036-1051.

8. Meredith, D. S., Laurence, J. S., and Firman, I. D. 1973. Ascospore release and dispersal in black leaf streak disease of bananas (Mycosphaerella fijiensis). Trans. Br. Mycol. Soc. 60:547-554.

9. Müller, E. 1979. Factors inducing asexual and sexual sporulation in fungi (mainly Ascomycetes). Pages 265-282 in: The Whole Fungus. B. Kendric, ed. National Museum of Natural Sciences, Ottawa.

10. Navas-Cortes, J. A., Trapero-Casas, A., and Jimenez-Diaz, R. M. 1998. Phenology of Didymella rabiei development on chickpea debris under field conditions in Spain. Phytopathology 88:983-991.

11. O'Leary, A. J., and Sutton, T. B. 1986. The influence of temperature and moisture on the quantitative production of pseudothecia of Venturia inaequalis. Phytopathology 76:199-204.

12. Pados-Ligero, A. M., Gonzalez-Andujar, J. L. Melero-Vara, J. M., and Basallote-Ureba, M. J. 1998. Development of Pleospora allii on garlic debris infected by Stemphylium vesicarium. Eur. J. Plant Pathol. 104: 861-870.

13. Ross, R. G., and Hamlin, S. A. 1962. Production of perithecia of Venturia inaequalis (Cke.) Wint on sterile apple leaf discs. Can. J. Bot. 40:525-527.

14. Russo, L. W., and Bistline, F. W. 1992. Results from thirteen year study to study effective spray timing with greasy spot (Mycosphaerella citri) spore population on east coast and ridge area groves. Proc. Fla. State Hortic. Soc. 105:19-20.

15. Timmer, L. W., and Gottwald, T. R. 2000. Greasy spot and similar diseases. Pages 25-28 in: Compendium of Citrus Diseases. L. W. Timmer, S. M. Garnsey, and J. H. Graham, eds. The American Phytopathological Society, St. Paul, MN.

16. Timmer, L. W., Reeve, R. J., and Davis, R. M. 1980. Epidemiology and control of citrus greasy spot on grapefruit in Texas. Phytopathology 70: 863-867.

17. Timmer, L. W., Roberts, P. D., Darhower, H. M., Bushong, P. M., Stover, E. W., Peever, T. L., and Ibañez, A. M. 2000. Epidemiology and control of citrus greasy spot in different citrus-growing areas in Florida. Plant Dis. 84:1294-1298.

18. Trapero-Casas, A., and Kaiser, W. J. 1992. Development of Didymella rabiei, the teleomorph of Ascochyta rabiei, on chickpea straw. Phytopathology 82:1261-1266.

19. Walker, J., and Baker, K. F. 1983. The correct binomial for the chrysanthemum ray blight pathogen in relation to its geographical distribution. Trans. Br. Mycol. Soc. 80:31-38.

20. Whiteside, J. O. 1970. Etiology and epidemiology of citrus greasy spot. Phytopathology 60:1409-1414.

21. Whiteside, J. O. 1972. Histopathology of citrus greasy spot and identification of the causal fungus. Phytopathology 62:260-263.

22. Whiteside, J. O. 1972. Effectiveness of spray materials against citrus greasy spot in relation to time of application and infection periods. Proc. Fla. State Hortic. Soc. 84:56-63.

23. Whiteside, J. O. 1973. The possibilities of using ground sprays to control citrus greasy spot. Proc. Fla. State Hortic. Soc. 86:19-23.

24. Whiteside, J. O. 1974. Environmental factors affecting infection of citrus leaves by Mycosphaerella citri. Phytopathology 64:115-120.

25. Whiteside, J. O. 1976. Epidemiology and control of greasy spot, melanose, and scab in Florida citrus groves. PANS (Pest Artic. News Summ.) 22:243-249.

26. Whiteside, J. O. 1977. Behavior and control of greasy spot in Florida citrus groves. Proc. Intl. Soc. Citricult. 3:981-986.

27. Whiteside, J. O. 1982. Timing of single-spray treatments for optimal control of greasy spot on grapefruit leaves and fruit. Plant Dis. 66:687690 .

28. Willson, E. E. 1928. Studies of the ascigerous stage of Venturia inaequalis (Cke.) Wint in relation to the certain factors of environment. Phytopathology 18:375-418. 